\title{
Undisturbed breeding penguins as indicators of changes in marine resources
}

\author{
Yvon Le Maho, Jean-Paul Gendner, Etienne Challet, Charles-André Bost, Janick Gilles, \\ Christophe Verdon, Christiane Plumeré, Jean-Patrice Robin, Yves Handrich
}

Centre d'Ecologie et Physiologie Energétiques, Centre National de la Recherche Scientifique,

23, rue Becquerel, F-67087 Strasbourg, France

\begin{abstract}
Trends in sea-bird population sizes reflect changes in marine resources, but are only visible after years. Sea-birds fast when breeding ashore and, therefore, breeding success largely depends upon body fuels accumulated at sea and food stored in the stomach for chicks. Using an automatic setup for identification and weighing of breeding king penguins Aptenodytes patagonicus, we demonstrate seasonal differences in the daily gain in body mass and duration of foraging trips of breeders at sea. Taking into account already available information, our data indicate that it takes longer for the breeders to obtain food when manine resources are decreasing. The overall gain in body mass of the birds at sea is unchanged. However, they accumulate larger body fuel reserves, which therefore increases their energetic safety margin at predictable times of lower food availability but reduces food brought back to the chicks. In contrast to these seasonal changes, variations in the duration of sojourns into the colony, when penguins come independently to feed the chicks, can be attributed to the stages of the breeding cycle. Our setup also enables discriminating when the breeding failure is either due to poor food provisioning at sea or to the inability of the birds to minimize the depletion of their energy reserves when ashore. Thus, it is now possible to use breeding penguins as continuous indicators of changes in marine resources, on a time-scale of only days or weeks, while at the same time avoiding human disturbance by entering colonies and handling the birds.
\end{abstract}

\section{INTRODUCTION}

Sea-birds rely on stored body fuels when ashore for breeding. Thus, monitoring sea-birds as indicators of changes in the food resources of the ocean and of global climatic changes, through variations in their breeding performance or population trends, has become of major interest (Boersma 1978, Anderson et al. 1980, Schreiber \& Schreiber 1984, Croxall et al. 1988 Aebisher et al. 1990, Taylor \& Wilson 1990, Trivelpiece et al. 1990). For example, fluctuations in demographic parameters of Sub-antarctic sea-bird populations in 1976-1987 were associated with El Niño/Southern Oscillation, ENSO, (Croxall et al. 1988) and a decrease in the breeding success of different colonies of puffins has been correlated to overfishing (Lid 1981, Brown \& Nettleship 1984). Using sea-birds as indicators of changes in marine resources may, in fact, be more accurate and more economical than trying to obtain measures of the prey stocks themselves (Cairns 1987).

However, trends in sea-bird population sizes can only be detected after years (Croxall et al. 1988). Among criteria assessed on a shorter time scale, an increased duration of the foraging trips of sea-birds associated with a decrease in marine resources has proved of considerable potential (Croxall et al. 1988). It results in a delay in the onset of breeding or, if breeding has already started, an increased risk of desertion by the land-bound breeding partner waiting to be relieved. Even if the delayed foraging bird returns on time, its body condition, i.e. fuel reserves and/or food stored for offspring, may be insufficient to insure successful breeding (Davis 1982). Stomach flushing enables monitoring changes in food stored for offspring without killing the parents (Wilson 1984), but is obviously stressful for the birds and detrimental for offspring sur- 
vival. Other methods are through the video monitoring of food given to chicks, as was done for terns (Frank 1988), or the automatic weighing of the chick, as for albatrosses (Prince \& Walton 1984). Such methods, however, cannot be used for a very large number of breeders, i.e. to take into account inter-individual variability, nor do they enable monitoring the changes in the body condition of the breeders. These may be assessed by weighing known adults at each arrival to and departure from the colony.

For such an investigation, penguins are advantageous because they breed in accessible colonies and exhibit large variations in body mass. A major problem, however, is that these birds are sensitive to humans entering colonies and handling, which can ultimately have a serious effect on their breeding performance (Culik \& Wilson 1991). The use of flipper bands with numbers large enough to be read at a distance allows identification of penguins without handling them. However, in order to avoid injuring the bird, especially during the molt when the flipper thick- ens, bands are loosely attached. This practice results in the loss of about $20 \%$ of the bands during the first year (Weimerskirch et al. 1992). As shown in the present study, with recent developments in technology, penguins may be automatically weighed and identified, which has allowed us to acquire the first data reflecting seasonal changes in the breeding and foraging performance of undisturbed breeding penguins.

\section{MATERIALS AND METHODS}

Animal model. The king penguin Aptenodytes patagonicus is of particular interest as an indicator of sea resources since it mostly feeds on major components of the Southern Ocean resources (myctophid fish and squid) (Adams \& Klages 1987, Cherel \& Ridoux 1992). Such a food specialist shows better the impact of food abundance than food generalists (Pierroti \& Annett 1990). There are extensive seasonal variations in ocean resources (Foxton 1956, Jacques et al. 1982)

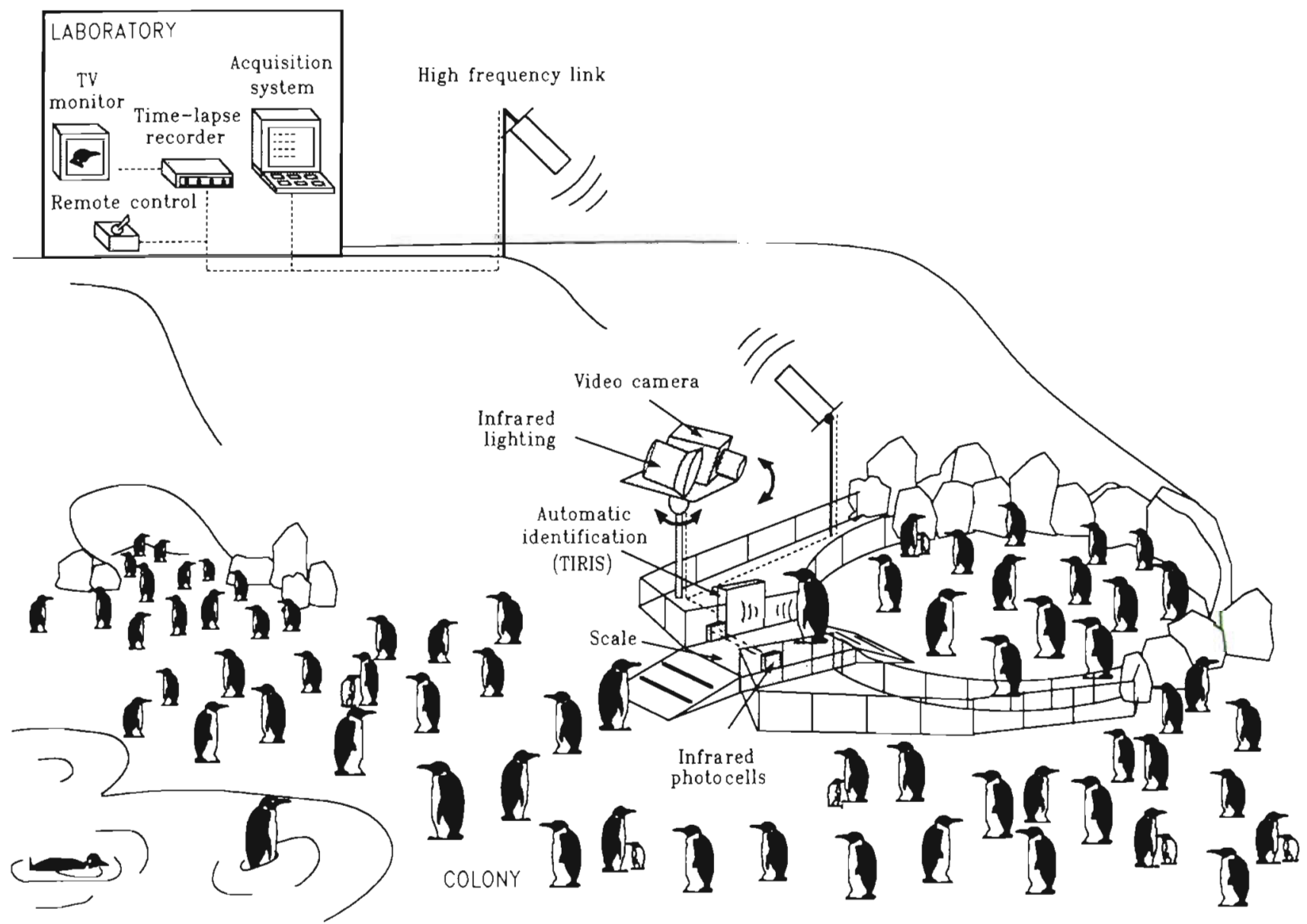

Fig. 1. Schematic design of the automatic system installed at Possession Island (Crozet Archipelago) in a breeding colony of king penguins (25000 to 40000 pairs). For details on the setup, see text 
during the breeding cycle of the birds. The chick's growth, rapid during the first summer abundance, is interrupted by winter food scarcity, and is only completed during the second summer. Thus, the breeding cycle takes longer than a year ( 14 mo) and early breeders that have successfully raised a chick can only be late breeders the next year. However, chicks of late breeders are unable to complete their pre-winter period of growth, which is explained by a drop in marine resources (Barrat 1976, Weimerskirch et al. 1992). That king penguins are alternately early and late breeders also excludes the usual complication for sea-birds that late breeders are essentially birds with poorer breeding and foraging experience (Ollason \& Dunnet 1978). Taking into account the numerous categories, e.g. early vs late breeders of both sexes, the monitoring of many identified individuals of known life history makes it possible to obtain a year-round index of ocean resources.

Experimental setup. In continuous use since 20 January 1991, the setup is based on the automatic weighing and identification of king penguins when passing over a weighbridge at the only opening to their breeding site (Fig. 1).

The site was chosen on a natural slope. This situation is common for king penguins and previous observations had shown that the birds prefer to pass at the lowest point of their breeding site. A part of the colony was enclosed in 1988 during the austral winter, before the onset of reproduction. Since then, about 200 pairs each year spontaneously settle therein for breeding. They have to pass the weighing platform on arrival or departure. Double fences prohibit mates attempting to relieve each other through the fence. A weighbridge is used to slow the birds when passing over the scale. Posts in a herring bone arrangement delimit the passageway and discourage the birds from sitting on the platform.

Individual identification is based on the new system TIRIS (Texas Instruments), used here for the first time in a wild animal. The transponder tags (length $30 \mathrm{~mm}$, diameter $3 \mathrm{~mm}$, mass $0.8 \mathrm{~g}$ ) are sterilely implanted under the bird's skin, with local anaesthesia. To minimize disturbance, birds are caught when departing from the study site. Recapture to replace batteries is unnecessary since the transponders are activated electromagnetically. The system enables identification at a distance of $0.7 \mathrm{~m}$ from the detector, which includes an electromagnetic field generator and is located at the weighbridge. For the present study, 150 birds were equipped with transponders.

Two infrared photocells indicate the direction of passage. Birds usually walk over the scale within 3 to $10 \mathrm{~s}$. All data are sent by a high frequency communication link $600 \mathrm{~m}$ away to a relay station on a cliff above the penguin colony and from there by cable to the scien- tific station. Sampling rate of the weighing signal is $20 \mathrm{~s}^{-1}$. Real time processing gives mean body mass. These values are later checked by interactive processing. Accuracy of measurement is between $\pm 30 \mathrm{~g}$ and $\pm 100 \mathrm{~g}$. depending on the waddling gait of the birds and wind velocity. Using infrared lighting at night, the birds may be observed by video. The camera orientation can be remotely controlled.

\section{RESULTS AND DISCUSSION}

\section{Seasonal changes vs differences in the breeding cycle}

There was a progressive and significant increase $(\mathrm{p}<$ 0.001 ) in the duration of the foraging trips at sea of both male and female breeders, from 5 to $7 \mathrm{~d}$ in February to ca 1 mo in May-June. The overall gain in body mass of the birds during these trips did not change significantly, remaining at about $3 \mathrm{~kg}$. Accordingly, as shown in Table 1, there was a dramatic seasonal drop in the mean daily gain in body mass of the breeders during their trips at sea.

Although the first incubation shift of late breeders (by the male) had a similar duration to that observed for early birds, the durations of later shifts was significantly longer in late breeders (Table 2). The lengthening of Shift 2 (by the female) had already been observed by Weimerskirch et al. (1992). Our data therefore demonstrate that this modification is not due to human disturbance.

Early and late breeders were compared at the same stage of the breeding cycle, when the 2 mates start to come independently to feed the chick, i.e. in February for early birds and April for late. The duration of forag-

Table 1. Aptenodytes patagonicus. Daily gains in body mass of king penguins during their foraging trips at sea, based on the changes in body mass of early breeders that were automatically identified and weighed at their departure from and return to the colony. Values are means \pm SE and significantly different $(p<0.01)$ in the same column when not sharing a common superscript letter. No. of penguins given in parentheses. As throughout this paper, data were compared for statistically significant differences using Peritz' $F$ test (Harper 1984)

\begin{tabular}{|lcc|}
\hline Period & $\begin{array}{c}\text { Daily gain in body mass }\left(\mathrm{kg} \mathrm{d}^{-1}\right) \\
\text { Males }\end{array}$ & Females \\
\hline February & $0.55 \pm 0.05^{\mathrm{a}}$ & $0.42 \pm 0.06^{\mathrm{d}}$ \\
& $(9)$ & $(9)$ \\
April & $0.24 \pm 0.08^{\mathrm{b}}$ & $0.15 \pm 0.05^{\mathrm{b}}$ \\
& $(7)$ & $(7)$ \\
May/June & $0.11 \pm 0.02^{\mathrm{b}}$ & $0.11 \pm 0.03^{\mathrm{b}}$ \\
& $(7)$ & $(5)$ \\
\hline
\end{tabular}


Table 2. Aptenodytes patagonicus. Duration (d) of incubation shifts for early and late breeders of king penguins. Means \pm SE. n: no. of penguins

\begin{tabular}{|lcccc|}
\hline Mate: & $\begin{array}{c}\text { Shift 1 } \\
\text { Male }\end{array}$ & $\begin{array}{c}\text { Shift 2 } \\
\text { Female }\end{array}$ & $\begin{array}{c}\text { Shift 3 } \\
\text { Male }\end{array}$ & $\begin{array}{c}\text { Shift 4 } \\
\text { Female }\end{array}$ \\
\hline $\begin{array}{l}\text { Early } \\
\text { breeders }\end{array}$ & $\begin{array}{c}17.3 \pm 0.3 \\
(\mathrm{n}=28)\end{array}$ & $\begin{array}{c}18.3 \pm 0.4 \\
(\mathrm{n}=28)\end{array}$ & $\begin{array}{c}15.3 \pm 0.4 \\
(\mathrm{n}=28)\end{array}$ & $\begin{array}{c}10.4 \pm 0.2 \\
(\mathrm{n}=28)\end{array}$ \\
$\begin{array}{l}\text { Late } \\
\text { breeders }\end{array}$ & $\begin{array}{c}17.8 \pm 1.0 \\
(\mathrm{n}=13)\end{array}$ & $\begin{array}{c}20.8 \pm 0.9^{\circ} \\
(\mathrm{n}=13)\end{array}$ & $\begin{array}{c}17.3 \pm 0.8^{*} \\
(\mathrm{n}=11)\end{array}$ & $\begin{array}{c}13.4 \pm 1.1^{\circ} \\
(\mathrm{n}=9)\end{array}$ \\
$\cdot \mathrm{p}<0.01$ vs early breeders & & \\
\hline
\end{tabular}

ing trips was significantly longer for late birds (Fig. 2). Foraging trip duration was, however, remarkably similar for both early and late breeders in April, i.e. at a different stage of breeding but the same time of the year (Fig. 2). This indicates that the extension of foraging trips at sea is a purely seasonal effect and not related to differences in the stage of breeding cycle.

The duration of the sojourns of breeders into the colony did not differ significantly between early breeders in February and late breeders in April, i.e. when the birds were at the same stage of the breeding cycle. Sojourn duration in April, moreover, was significantly shorter $(p<0.001)$ in early breeders than in late (Fig. 2). Early breeders had larger chicks at that time, which
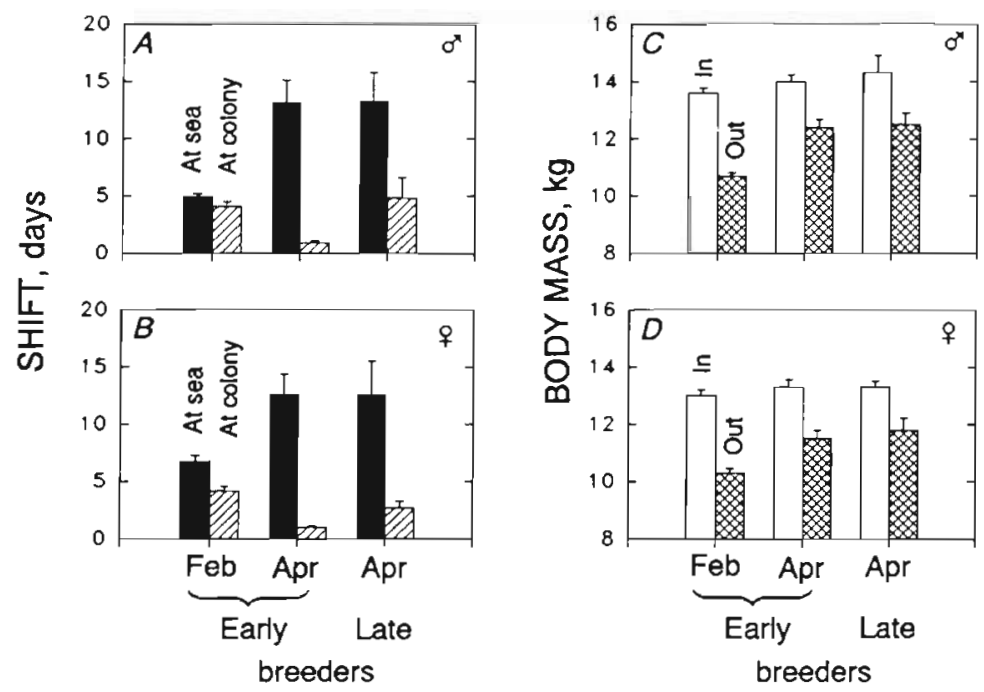

Fig. 2. Aptenodytes patagonicus. Duration of shifts at sea (assuming all time outside the colony is spent at sea) and in the colony, body masses at arrival in colony (In) and departure (Out), of early and late breeders of king penguins. Means \pm SE. Sample numbers for birds of either sex: early breeders in February: 18 each; early breeders in April: 14 to 16; late breeders: 6 to 8 . There was a longer duration $(p<0.01)$ of foraging shifts at sea in April (seasonally lower sea resources) associated with a lower body mass loss $(p<0.01)$ in the colony (indicating a lower food delivery to chicks) could therefore ingurgitate a similar amount of food more quickly. Thus, in contrast to the duration of foraging trips at sea, the duration of breeder's sojourns into their colony, at the time both mates are independent from each other, is primarily related to the stage in breeding cycle, not to seasonal changes.

When considering the changes in body masses of breeders as reflecting variations in food availability, it obviously is of a particular interest to discriminate between their changes in body fuel reserves and food stored for chicks. First, the fairly constant body mass of incoming birds (Fig. 2) is quite remarkable since the mass delivered to chicks is carried as partially digested prey. This may reflect some set-point for body mass on return to the colony but does not necessarily imply that the relative proportion of body fuel reserves and stomach content is constant. In fact, assuming that all food stored in the stomach has been delivered to their chicks when breeders leave their colony, the significantly larger body masses of the birds departing in April, as illustrated in Fig. 2, indicate that they had arrived with lower stomach content and larger body fuel reserves. The similarity between the departure and arrival body masses of early and late breeders at this same period of the year, for both sexes, moreover demonstrates that this change is environmental and not due to a different stage of breeding. When the parent's visit to the chick is short enough, the amount of food delivered can be ascertained, because the utilization of body fuels by the parent is almost negligible. Indeed, in May-June, after 1 mo of foraging at sea, the parents went back and forth $4 \pm 1$ times over $10 \pm 1 \mathrm{~d}$ ( $\mathrm{n}=$ 20) and food was essentially delivered during the first visit. Those coming in and out within $9 \mathrm{~h}$ or less delivered no more than $0.71 \pm$ $0.13 \mathrm{~kg}(\mathrm{n}=7)$. Considering that this figure may still overestimate food regurgitated, due to some decrease in body fuel reserves of the parent and some digestion of stomach content (Wilson et al. 1989), it fits very well with the $0.6 \mathrm{~kg}$ provisioning determined at that winter time by stomach flushing (Cherel et al. 1993). This is only one-third of the $1.8 \mathrm{~kg}$ provisioning after $6 \mathrm{~d}$ of foraging in February (Cherel \& Ridoux 1992).

\section{Seasonal changes in relation to marine resources}

The observed seasonal drop in food brought back to chicks and the increase in the duration of foraging trips of breeding king penguins, between February and April, obviously correspond with the mid-April 
drop in the number of adults entering the colony, interruption of chick growth, lower body mass of late breeders' chicks when forming crèches, and rise in starvation-induced mortality of chicks, particularly for late breeders (Stonehouse 1960, Barrat 1976). Moreover, there is a drop in the proportion of fish in king penguin diet in mid-April. All these changes are attributed to a general lower availability of fish prey in the Southern Oceanic regions (Adams \& Klages 1987. Cherel et al. 1993). The lower availability of king penguin fish prey is probably due to its deeper migration in winter, as found in the Southern Atlantic Ocean (Sabourenkov 1991). That breeding king penguins build larger body fuel reserves at the time their fish prey is less available, as shown above, may be interpreted as reflecting the need for a greater safety margin in breeders' body fuels when resources are poorer. This energetic strategy must be a key feature of king penguins since, as also shown above by our data, it is observed for both early and late breeders. This is not surprising. The king penguin is a long-lived bird (Weimerskirch et al. 1992) and such birds are expected to follow strategies increasing chances of survival rather than breeding success.

\section{Discrimination of reasons for breeding failure}

Until now, it was also impossible to discriminate the breeding failures of penguins due to their body condition from those failures due to repeated disturbances by the investigators. With our setup, we found that the arrival body masses of the few individuals that abandoned before the normal time of relief were about $3 \mathrm{~kg}$ lower than those of the breeders which left normally after being relieved. Penguins are known to stop their fast before a critical depletion in their body fuels (Le Maho et al. 1988), and so abandonment by the few individuals may be attributed to insufficient storage of body fuels at sea. Another problem, until now, was to discriminate those abandonments that, instead of resulting from insufficient initial body fuel reserves, are the simple consequence of an excessive rate of depletion of the body fuels of the fasting birds in the colony. A simple criterion may now be a faster body mass loss of the birds. Moreover, among those behaviours which likely represent a major energy cost, we investigated territorial defence, i.e. when the birds vigorously defend the territory that can be delimited by beak and flippers. Based on continuous video recordings, 5 breeders spent on average as much as $6 \mathrm{~h}$ per $24 \mathrm{~h}$ defending their territory (369 \pm 121 min), which represents about 2500 pecks. Of these $6 \mathrm{~h}$, about $2.5 \mathrm{~h}$ (146 min) corresponded to pecking and/or battling at night. With so much time spent in defence, the location of individuals in relation to neighbours in the colony may be a key determinant in their energy budget. In addition to territorial defence, king penguins are still feeding their chicks at night. They also continue to move between the colony and the sea. Of 700 passages of identified breeders between the end of January and the end of March, 19\% occurred at night. Thus, the maintenance of territorial defence, movements and breeding tasks, i.e. the absence of clearly defined periods of rest, precludes the possibility that penguins may compensate poor storage of food at sea by energy saving through long periods of sleep in the colony.

\section{CONCLUSION}

The present investigation concerned 150 breeding birds, but the close survey of thousands is possible, therefore enabling comparison with the performances of individual birds at population levels and without human presence in their colonies. Thus, we demonstrate here that it is now possible to automatically monitor changes in the breeding and foraging parameters of populations of breeding penguins and to discriminate between changes that are either due to the stage of the breeding cycle or reflect seasonal variations in marine resources. Major indices of these seasonal variations, as shown in the present study, may be found by combining the information based on the duration of penguins' foraging trips at sea and on their changes in body mass during those trips. It is therefore of particular interest that the duration of foraging trips has also appeared as a critical parameter when considering the use of sea-birds and mammals as bio-indicators of inter-year environmental changes such as the ENSO (Croxall et al. 1988). The potential of using our setup for monitoring global changes may moreover be further enhanced by coupling it to the use of portable data-loggers or satellite transmitters, enabling the foraging performance of penguins at sea to be investigated (Naito et al. 1990, Wilson et al. 1991, Ancel et al. 1992, Kooyman et al. 1992).

Acknowledgements. We thank Y. Cherel, J. Croxall and A. Malan for critical comments on earlier manuscripts, X. Reboud for help in a pilot study and the 1991 winter team in Crozet for technical help. We also thank H. Massink and J.-P. Bruneval from Texas Instruments Holland and France, respectively, for enabling this first use of the TIRIS identification system on a wild animal. This work was supported by grants from the Mission de Recherche, Terres Australes et Antarctiques Françaises, the EEC (grant on new techniques in undisturbed animals), CNRS and Université Louis Pasteur. 


\section{LITERATURE CITED}

Adams, N. J., Klages, N. T. (1987). Seasonal variation in the diet of the King penguin (Aptenodytes patagonicus) at sub-Antarctic Marion Island. J. Zool. Lond. 212: 303-324

Aebischer, N. J., Coulson, J. C., Colebrook, J. M. (1990). Parallel long-term trends across four marine trophics levels and weather. Nature 147: 753-755

Ancel, A., Kooyman, G. L., Ponganis, P. J., Gendner, J.-P., Lignon, J., Mestre, X., Huin, N., Thorson, P. H., Robisson, P., Le Maho, Y. (1992). Foraging behaviour of emperor penguins as a resource detector in winter and summer. Nature 360: 336-339

Anderson, D. G., Gress, F., Mais, K. F. (1980). Brown pelican: influence of food supply on reproduction. Oikos 39: 23-31

Barrat, A. (1976). Quelques aspects de la biologie et de l'écologie du Manchot royal (Aptenodytes patagonicus) des lles Crozet. Com. natn. fr. Rech. antarct. 40: 9-52

Boersma, P. D. (1978). Breeding patterns of Galapagos penguins as an indicator of oceanographic conditions. Science 200: 1481-1483

Brown, R. G., Nettleship D. N., (1984). Capelin and seabirds in the Northwest Atlantic. In: Nettleship, D. N., Sanger, G. A., Springer, P. F. (eds.) Marine birds: their feeding ecology and commercial fisheries relationships. Canadian Wildlife Service Publication, Ottawa, Ontario, p. 184-195

Cairns, D. K. (1987). Seabirds as indicators of marine food supplies. Biol. Oceanogr. 5: 261-271

Cherel, Y., Ridoux, V. (1992). Prey species and nutritive value of food fed during summer to King penguin Aptenodytes patagonica chicks at Possession Island, Crozet Archipelago. Ibis 134: 118-127

Cherel, Y., Verdon, C., Ridoux, V. (1993). Seasonal importance of oceanic myctophids in king penguin diet at Crozet Islands. Polar. Biol. (in press)

Croxall, J. P., McCann, T. S., Prince, P. A., Rothery, P. (1988). Reproductive performance of seabirds and seals at South Georgia and Signy Island, South Orkney Island, 1976-1987. Implications for Southern Ocean monitoring studies. In: Sahrhage, D. (ed.) Antarctic Ocean and resource variability. Springer-Verlag, Berlin, p. 261-285

Culik, B., Wilson, R. (1991). Penguins crowded out? Nature 351: 340

Davis, L. S. (1982). Timing of nest relief and its effect on breeding success in Adélie penguins (Pygoscelis adeliae) Condor 84: $178-183$

Foxton, P. (1956). The distribution of the crop of zooplankton in the Southern Ocean. Discovery Rep. 28: 191-236

Frank, D. (1988). Fütterrrate und Nahrungszusammensetzung von Fluss-Seeschwalben (Sterna hirundo) anhand automatischer Registrierung am Nest. PIoc. Int. 100. DO-G Meeting, Current Topics Avian Biol., Bonn, p. $159-165$

Harper, J. F. (1984). Peritz' F test: basic program of a robust multiple comparison test for statistical analysis of all differences among group means. Comput. biol. Med. 14: $437-445$
Jacques, G., De Billy, G., Panouse, M. (1982). Biomasse et production primaire dans les secteurs antarctiques et subantarctiques de l'Océan Indien (Mars 1980). CNFRA 53 $87-99$

Kooyman, G. L., Cherel, Y., Le Maho, Y., Croxall, J. P., Thorson, P. H., Ridoux, V., Kooyman, C. A. (1992). Diving behaviour and energetics during foraging cycles in King penguins. Ecol. Monogr. 62: 143-163

Le Maho, Y., Robin, J. P., Cherel, Y. (1988). Starvation as a treatment for obesity: the need to conserve body proteins. News Physiol. Sci. 3: 21-24

Lid, G. (1981). Reproduction of the puffin on rost in the Lofoten Islands in 1964-1980. Cinclus 4: 30-39

Naito, Y., Asaga, T., Ohyama, Y. (1990). Diving behavior of Adélie penguins determined by time-depth recorder. Condor 92: 582-586

Ollason, J. C., Dunnet, G. M. (1978). Age, experience and other factors affecting the breeding success of the fulmar (Fulmarus glacialis) in Orkney. J. Anim. Ecol. 47: 961-976

Pierroti, R., Annett, C. A. (1990). Diet and reproductive output in seabirds. BioSci. 40:568-574

Prince, P. A., Walton, D. W. H. (1984). Automated measurement of meal sizes and feeding frequency in Albatrosses. J. appl. Ecol. 21: 789-794

Sabourenkov, E. N. (1991) Mesopelagic fish of the Southern Ocean - Summary results of recent Soviet studies. CCAMLR Selected Scientific Papers: 1990: 433-457

Schreiber, R. W., Schreiber, E. A. (1984). Central Pacific seabirds and the El Nino Southern Oscillation: 1982 to 1983 perspectives. Science 225: 713-716

Stonehouse, B. (1960). The King penguin Aptenodytes patagonica of South Georgia. I. Breeding behaviour and development. Sci. Rep. Falkland Isl. Depend. Surv. 23: 1-81

Taylor, R. H., Wilson, P. R. (1990). Recent increase and southern expansion of Adélie penguin populations in the Ross Sea, Antarctica, related to climatic warming. N.Z. J. Ecol. 14: $25-29$

Trivelpiece, W., Trivelpiece, S., Geupel, G. R., Kjelmyr, J., Volkman, N. J. (1990). Adélie and Chinstrap penguins: their potential as monitors of the Southern Ocean marine ecosystem. In: Kerry, K. R., Hempel, G. (eds.) Antarctic ecosystems. Ecological change and conservation. Springer-Verlag, Berlin, p. 191-202

Weimerskirch, H., Stahl, J. C., Jouventin, P. (1992). The breeding biology and population dynamics of King penguins Aptenodytes patagonica on the Crozet Islands. Ibis 134: $107-117$

Wilson, R. P. (1984). An improved stomach pump for penguins and other seabirds. J. Field Ornithol. 55: 109-111

Wilson, R. P., Ryan, P. G. Wilson, M. P. (1989). Sharing food in the stomachs of seabirds between adults and chicks. A case for gastric emptying. Comp. Biochem. Physiol. 94A: $461-466$

Wilson, R. P., Culik, B. M., Adelung, D., Spairani, H. J., Coria, N. R. (1991). Depth utilisation by breeding Adélie penguins, Pygoscelis adeliae, at Esperanza Bay, Antarctica. Mar. Biol. 109: 181-189

Manuscript first received: June 25, 1992

Revised version accepted: February 18, 1993 